\title{
Antagonistic activity of rhizobacteria in the inhibition of the fungus Pseudocercospora griseola (Sacc.)
}

\section{Atividade antagonista de rizobactérias na inibição do fungo Pseudocercospora griseola (Sacc.)}

\section{Tayla Évellin de OLIVEIRA ${ }^{1}$; Maria de Lourdes RESENDE²; Ligiane Aparecida FLORENTINO³; Nhayandra Christina Dias e SILVA ${ }^{4}$}

\begin{abstract}
${ }^{1}$ Autor para correspondência, Doutoranda no Programa de Pós-graduação em Agricultura Sustentável pela Universidade José do Rosário Vellano - UNIFENAS. E-mail: taylaeoliveira@hotmail.com

${ }^{2}$ Doutora, Professora Pesquisadora. Universidade José do Rosário Vellano - UNIFENAS. E-mail: maria.resende@unifenas.br ${ }^{3}$ Doutora, Professora Pesquisadora. Universidade José do Rosário Vellano - UNIFENAS. E-mail: ligiane.florentino@unifenas.br ${ }^{4}$ Doutora, Pós-Doutoranda no Programa de Pós-graduação em Ciência Animal pela Universidade José do Rosário Vellano UNIFENAS. Universidade José do Rosário Vellano - UNIFENAS. E-mail: nhayandra_dias@yahoo.com.br
\end{abstract}

Recebido em: 11-06-2019; Aceito em: 05-10-2020

\begin{abstract}
The angular leaf spot caused by the fungus Pseudocercospora griseola (Sacc.) is one of the main diseases in bean plants. Considering the losses caused by this disease, rhizobacteria may be an alternative for the management of this phytopathogen. Thus, this study evaluates the potential of different strains of rhizobacteria in the inhibition of the fungus $P$. griseola (Sacc.). The antagonistic effect of twenty bacterial strains on this phytopathogen was studied using the circle technique. The completely randomized experimental design was used with five repetitions. Evaluation was performed on the tenth day, when colony diameter was measured and the percentage of growth inhibition (PGI) of the pathogen was calculated. Twelve strains inhibited the mycelial growth of $P$. griseola (Sacc.), with PGI values above $40 \%$ compared to the control. The strain UNIFENAS 03-36 stood out with inhibition percentage of $85.10 \%$.
\end{abstract}

Additional keywords: alternative control; angular leaf spot; Phaseolus vulgaris L.

\section{Resumo}

A mancha angular causada pelo fungo Pseudocercospora griseola (Sacc.) é uma das principais doenças que ocorrem no feijoeiro. Considerando as perdas causadas por essa doença as rizobactérias podem ser uma possível alternativa para o manejo desse fitopatógeno. Com base nisso, o objetivo deste estudo foi avaliar o potencial de diferentes estirpes de rizobactérias na inibição do fungo $P$. griseola (Sacc.). Foram estudadas o efeito antagonista de 20 estirpes bacterianas nesse fitopatógeno, utilizando a técnica de círculo. O delineamento experimental utilizado foi inteiramente casualizado com cinco repetições. A avaliação foi efetuada no décimo dia, onde foram medidos o diâmetro da colônia e calculado a percentagem de inibição de crescimento (PIC) do patógeno. Doze estirpes foram eficazes na inibição do crescimento micelial do $P$. griseola (Sacc.) com valores de PIC acima de $40 \%$, em relação ao controle. A estirpe UNIFENAS 03-36 destacou-se com um percentual de inibição de 85,10\%.

Palavras-chave adicionais: controle alternativo; mancha angular; Phaseolus vulgaris $\mathrm{L}$.

\section{Introduction}

Common beans (Phaseolus vulgaris L.) are prominent in Brazilian agriculture, being considered a staple food as an accessible source of proteins, fibers, carbohydrates, and minerals (CONAB, 2016). According to the Brazilian Institute of Geography and Statistics (IBGE), the bean crop for 2020 is estimated at 2.9 million tons.

However, bean production can be affected by several factors, including diseases such as anthracnose, white mold, angular spot, rust, and fusarium wilt. Of these, the angular leaf spot, whose etiologic agent is the fungus Pseudocercospora griseola (Sacc.) highlights for being considered one of the most important diseases, and found in almost all regions where com- mon beans are grown (Wendland et al., 2016), causing losses of up to $70 \%$ (Fancelli \& Dourado Neto, 2007).

Chemical management is the main practice for controlling this pathogen, which is still a fundamental mechanism as the disease causes significant losses in production. However, intensive use of chemicals contaminates soil and water, increasing damage to the environment (Spadotto et al., 2010). Thus, there is an increasing trend towards the search for biological agents that are practically non-toxic, with reduced costs of obtaining and use, and that have specificity between biological and etiological agents of control.

A possible alternative for the management of angular leaf spot is the use of soil bacteria named rhizobacteria, which have the ability to develop inside the roots of some plants. These microorganisms can 
provide plants with better development and inhibition of pests or pathogens caused by phytopathogenic fungi through direct antagonism or induction of resistance (Latha et al., 2011; Wu et al., 2014; Vejan et al., 2016). Thus, the use of rhizobacteria reduces the risk of environmental damage and has promising results (Furlani et al., 2007).

Therefore, this study evaluates the potential of different strains of rhizobacteria in the inhibition of the fungus $P$. griseola (Sacc.).

\section{Material and methods}

The tests were performed at the Soil Microbiology Laboratory (LMS) of José do Rosário Vellano University - UNIFENAS, Alfenas campus.

Twenty bacterial strains from the LMS collection were used, whose morphological characteristics are shown in table 1.

Table 1 - Morphological characteristics of bacterial strains cultured in YMA culture medium using the blue bromothymol indicator.

\begin{tabular}{|c|c|c|c|}
\hline Bacterial strains & $\mathrm{pH}$ & $\begin{array}{c}\text { Production of } \\
\text { exopolysaccharides }\end{array}$ & Color \\
\hline & \multicolumn{3}{|c|}{ Strains of Phaseolus vulgaris } \\
\hline UNIFENAS 02-10 & Ácid & High & Cream \\
\hline UNIFENAS 02-11 & Ácid & High & Yellow \\
\hline \multirow[t]{2}{*}{ UNIFENAS 02-12 } & Ácid & High & Yellow \\
\hline & \multicolumn{3}{|c|}{ Strains of Gliricidia sepium } \\
\hline UNIFENAS 03-10 & Ácid & Low & Yellow \\
\hline UNIFENAS 03-12 & Ácid/ Alkaline & Low & Yellow \\
\hline UNIFENAS 03-13 & Neutral & Medium & Cream \\
\hline UNIFENAS 03-14 & Alkaline & Low & Cream \\
\hline UNIFENAS 03-16 & Ácid & Low & Yellow \\
\hline UNIFENAS 03-23 & Alkaline & Low & Cream \\
\hline UNIFENAS 03-24 & Alkaline & Low & Cream \\
\hline UNIFENAS 03-25 & Alkaline & Low & White \\
\hline UNIFENAS 03-27 & Neutral & Medium & Cream \\
\hline UNIFENAS 03-29 & Neutral & Medium & Cream \\
\hline UNIFENAS 03-30 & Neutral & Medium & Cream \\
\hline UNIFENAS 03-31 & Ácid & Medium & Cream \\
\hline UNIFENAS 03-33 & Ácid/ Alkaline & Medium & Yellow \\
\hline UNIFENAS 03-34 & Ácid & Medium & Yellow \\
\hline UNIFENAS 03-35 & Ácid & Medium & Yellow \\
\hline UNIFENAS 03-36 & Neutral & Low & Yellow \\
\hline UNIFENAS 03-38 & Ácid & Low & Yellow \\
\hline
\end{tabular}

The fungus $P$. griseola (Sacc.) was isolated from the pod of a bean plant with lesions typical of angular leaf spot, a disease caused by this fungus. Lesions in the pods are dark brown with dark edges, rounded and superficial (Amorim et al., 2018). Isolation was performed indirectly with surface disinfestation in $70 \%$ alcohol, $2 \%$ sodium hypochlorite solution, and sterile water (Alfenas et al., 2016). The suspension obtained was applied to Petri dishes containing V8 medium (12 $\mathrm{g}$ of agar, $3 \mathrm{~g}$ of $\mathrm{CaCO}_{3}, 100 \mathrm{~mL}$ of $\mathrm{V} 8$ tomato juice, and $900 \mathrm{~mL}$ of water) (Miller, 1955). Then, dishes were incubated at $26 \pm 0.5 \stackrel{\circ}{\circ}$ for ten days in a BOD incubator under 12-hour photoperiod until spore formation. After this period, the isolated fungus was analyzed for its morphological characteristics (Barnett, 1972).

The bacterial strains used were cultured in YMA (yeast mannitol agar) culture medium (Vincent, 1970) for three days, enough time for emergence of isolated colonies. The fungus was grown in V8 medium (Miller, 1955) at temperature of $26 \pm 0.5^{\circ} \mathrm{C}$ until the dish was completely filled.
The method used was the circle technique, transferring a plate with fungus mycelium to the center of Petri dishes containing V8 culture medium. The bacteria were inoculated with the aid of a platinum loop, on the same dish, forming a circle around the dish containing the phytopathogen. For the control treatment, only the phytopathogen grown in V8 medium was used (Mariano, 1993).

Subsequently, dishes were incubated in a BOD under a 12-hour photoperiod at a temperature of $26 \pm 0.5^{\circ} \mathrm{C}$. The evaluation was performed on the tenth day, when the diameter of fungal colonies was measured in two diametrically opposed directions, with the aid of a caliper, defining means for each colony.

Means were used to calculate the percentage of mycelial growth inhibition (PGI), according to the formula of Menten et al. (1976), where:

$\mathrm{PIC}=\frac{\text { (Control growth-treatment growth)100 }}{\text { Control growth }}$ 
The experiment was performed in a completely randomized design with twenty-one treatments and five repetitions of each treatment, with each Petri dish as an experimental unit. All data were evaluated for frequency distribution and homogeneity of variances using histograms and formal statistical tests, being submitted to analysis of variance by the statistical program $R(R$ Core Team, 2018). Means were compared by Scott-Knott test at $5 \%$ probability.

\section{Results and discussion}

Under the conditions studied, some strains showed inhibitory effect on the mycelial growth of the fungus when subjected to the laboratory experiment using the circle technique. There was inhibition of mycelial growth when compared to the control (Table 2; $p<0.05)$.

Table 2 - Inhibition of mycelial growth of Pseudocercospora griseola (Sacc.) by rhizobacteria.

\begin{tabular}{lcc}
\hline Strains & Colony diameter $(\mathrm{cm})$ & Inhibition of mycelial growth (\%) \\
\hline UNIFENAS 03-36 & $1.34 \mathrm{a}$ & 85.10 \\
UNIFENAS 03-35 & $1.98 \mathrm{~b}$ & 80.21 \\
UNIFENAS 03-10 & $2.24 \mathrm{c}$ & 75.10 \\
UNIFENAS 03-31 & $2.36 \mathrm{c}$ & 73.77 \\
UNIFENAS 03-16 & $2.52 \mathrm{c}$ & 71.99 \\
UNIFENAS 03-13 & $2.56 \mathrm{c}$ & 71.54 \\
UNIFENAS 02-11 & $3.02 \mathrm{~d}$ & 66.44 \\
UNIFENAS 03-12 & $4.24 \mathrm{e}$ & 52.88 \\
UNIFENAS 03-23 & $4.38 \mathrm{f}$ & 51.33 \\
UNIFENAS 03-25 & $5.00 \mathrm{f}$ & 44.44 \\
UNIFENAS 03-27 & $5.00 \mathrm{f}$ & 44.44 \\
UNIFENAS 03-24 & $5.00 \mathrm{f}$ & 44.44 \\
UNIFENAS 02-10 & $9.00 \mathrm{~g}$ & 0.00 \\
UNIFENAS 02-12 & $9.00 \mathrm{~g}$ & 0.00 \\
UNIFENAS 03-29 & $9.00 \mathrm{~g}$ & 0.00 \\
UNIFENAS 03-30 & $9.00 \mathrm{~g}$ & 0.00 \\
UNIFENAS 03-33 & $9.00 \mathrm{~g}$ & 0.00 \\
UNIFENAS 03-34 & $9.00 \mathrm{~g}$ & 0.00 \\
UNIFENAS 03-38 & $9.00 \mathrm{~g}$ & 0.00 \\
UNIFENAS 03-14 & $9.00 \mathrm{~g}$ & 0.00 \\
CONTROLE & $9.00 \mathrm{~g}$ & 0.00 \\
\hline
\end{tabular}

* Averages followed by the same letter in the column do not differ by the Scott-Knott test ( $p>0.05)$. CV $=6.44 \%$.

Of the twenty strains tested, twelve inhibited the mycelial growth of the phytopathogenic fungus $P$. griseola (Sacc.). However, different values were found regarding the percentage of inhibition (Table 2).

The strain UNIFENAS 03-36 stood out for inhibiting the mycelial growth of $P$. griseola (Sacc.), with the smallest colony diameter and PGI of $85.10 \%$, followed by strains UNIFENAS 03-35, 03-10, 03-31, 03-16, 03-13, 03-12, 03-23, 03-25, 03-27, and 03-24, with PGI ranging from $80.21 \%$ to $44.44 \%$. According to Lanna et al. (2010), studies infer that percentages of mycelial growth inhibition with values of $40 \%$ or more indicate potential as a biological control agent, corroborating the results of this study.

Lima et al. (2014) obtained similar results when studying the in vitro antifungal action of isolates of rhizobacteria of the genus Bacillus ssp. on Fusarium oxysporum f. sp. lycopersici, who also observed potential for mycelial growth inhibition by circle technique. Ishida et al. (2008) found that rhizobacteria reduced the severity of the angular leaf spot of cotton when used in seed treatment. Several authors verified antagonistic potential of rhizobacteria with good results in inhibiting the growth of phytopathogenic fungi (Kupper et al., 2003; Furlani et al., 2007; Singh et al. 2011; Konusny-Andreani et al., 2014; Vafadar et al., 2014).

It is essential to perform in vitro and field testing to confirm the antagonistic potential of these microorganisms, as differences in inhibition can be observed in the field (Yan et al., 2011; Sharma et al., 2013).

\section{Conclusion}

The rhizobacteria evaluated in this study were effective in inhibiting the mycelial growth of Pseudocercospora griseola (Sacc.) by circle method.

\section{Acknowledgment}

To the Research Support Foundation of the State of Minas Gerais (FAPEMIG), for granting financial support to research. 


\section{References}

Alfenas AC, Mafia RG (2016) Métodos em Fitopatologia. UFV/VIÇOSA. $516 \mathrm{p}$.

Amorim L, Bergamin Filho A, Resende JAM (2018) Manual de fitopatologia. SÃO PAULO/AGRONÔMICA CERES. 573 p.

Barnett HL, Hunter BB (1972) Illustrated genera of imperfect fungi. Minneapolis, Burgess Publishing Company. 241p.

CONAB (2016) Companhia Nacional de Abastecimento - Feijão, Available at <https://www.conab.gov.br> (accessed fev 5 2019).

IBGE (2019) Instituto Brasileiro de Geografia e Estatística - Agência de Notícias IBGE, Available at $<$ https://agenciadenoticias.ibge.gov.br/> (accessed Oct 012020 ).

Fancelli AL, Dourado Neto D (2007) Produção de feijão. ESALQ/USP. 386p.

Furlani ACFA, Camargo M, Panizzi RC, Pereira CF (2007) Atividade de células, filtrado e autoclavado de Bacillus spp. como bioagentes de controle de Colletotrichum acutatum. Científica 35(2):196-200.

Ishida AKN, Souza RM, Resende MLV, Zacaroni AB, Vilas Bôas CH, Souza JT (2008) Rizobactérias no controle da mancha angular do algodoeiro. Ciênc. agrotec. 32(1):149-156.

Konusny-Andreani DI, Agiado JC, Junior, RA (2014) Efeito de bactérias rizosféricas sobre o desenvolvimento da cenoura. Revista da Universidade Vale do Rio Verde 12(1):211-220.

Kupper KC, Gimenes-Fernandes N, Goes A (2003) Controle biológico de Colletotrichum acutatum, agente causal da queda prematura dos frutos cítricos. Fitopatologia Brasileira, Brasília 28(3):251-257.

Lanna FR, Ferro HM, Pinho RSC (2010) Controle biológico mediado por Bacillus subtilis. Revista Trópica - Ciências Agrárias e Biológicas 4(2):12-20.

Latha P, Anand T, Prakasam V, Jonathan El, Paramathma M, Samiyappan R (2011) Combining Pseudomonas, Bacillus and Trichoderma strains with organic amendments and micronutrient to enhance suppression of collar and root rot disease in physic nut. Applied Soil Ecology 49:215-223.

Lima ODR, Santos, MSB, Rodrigues AAC (2014) Ação antifúngica in vitro de isolados de Bacillus sp. sobre Fusarium oxysporum f. sp. Iycopersici. Revista Caatinga 27(4):57-64.

Mariano RLR (1993) Métodos de seleção in vitro para o controle microbiológico de patógenos de plantas. Revisão Anual de Patologia de Plantas 1:369-409.
Menten JOM et al. (1976) Efeito de alguns fungicidas no crescimento micelial de Macrophomina phaseolina (Tass.) Goid. "in vitro". Fitopatologia Brasileira 1(2):5766.

Miller PM (1955) V-8 juice agar as a general-purpose medium for fungal and bacteria. Phytopathology 45: 461-462.

Sharma SCD, Shovon MS, Jahan MGS, Asaduzzaman AKM, Rahaman MA, Biswas KK, Abe NR (2013) Antibacterial and cytotoxic activity of Bacillus methylotrophicus-scs 2012 isolated from soil. Journal of Microbiology Biotechnology and Food Sciences 2(4):2293-2307.

Singh JS, Pandey VC, Singh PD (2011) Efficient soil microorganisms: a new dimension for sustainable agriculture an environmental development. Agriculture 140(3-4):339-353.

Spadotto CA, Scorza Junior RP, Dores EDC, Gebler L, Moraes DDC (2010) Fundamentos e aplicações da modelagem ambiental de agrotóxicos. Embrapa Monitoramento por Satélite-Documentos. Available at $<$ https://www.infoteca.cnptia.embrapa.br/infoteca/bitstr eam/doc/882588/1/Doc78.pdf> (accessed Feb 19 2019).

R Core Team (2018). R: A language and environment for statistical computing. R Foundation for Statistical Computing, Vienna, Austria. Available at <https://www.R-project.org/> (accessed Mar 25 2019).

Vafadar F, Amooaghaie R, Otrosha, M (2014) Effects of plant-growth-promoting rhizobacteria and arbuscular mycorrhizal fungus on plant growth, stevioside, NPK, and chlorophyll content of Stevia rebaudiana. Journal of Plant Interactions 9(1):128-136.

Vincent JMA. (1970) Manual for the practical study of root-nodule bacteria. Oxford, Blackwell Scientific Publications. $164 \mathrm{p}$.

Vejan, $P$, Abdullah, R, Khadiran, T, Ismail, S, Nasrulhaq BA (2016) Role of plant growth promoting rhizobacteria in agricultural sustainability - a review. Molecules, Basel, 21(5):573.

Wendland A, Moreira AS, Bianchini A, Giampan JS, Lobo Junior M (2016) Doenças do Feijoeiro. In: Amorin L, Rezende JAM, Bergamini Filho A, Camargo LEA. Manual de Fitopatologia - Doenças de Plantas Cultivadas. Agronômica Ceres 2(5):383-396.

Wu Y, Yuan J, Raza W, Shen Q, Huang Q (2014) Biocontrol traits and antagonistic potential of Bacillus amyloliquefaciens Strain NJZJSB3 against Sclerotinia sclerotiorum, a causal agent of canola stem rot. J. Microbiol. Biotechnol 24(10):1327-1336.

Yan X, He L, Song G, Wang R (2011) Antagonistic bioactivity of endophytic strains isolated from Salvia Miltiorrhiza. African Journal Biotechnology 10(67):15117-15122. 